\title{
BETTER WITH OZONE, OR NOT? AN IN-VIVO STUDY OF OZONE
THERAPY AS A PRE-TREATMENT BEFORE FISSURE SEALANT
APPLICATION
}

\section{ABSTRACT}

Objectives: The aim of the study was to evaluate clinical achievements of Clinpro $^{\mathrm{TM}}$ sealant and Teeth mate $\mathrm{F}-1$ fissure sealants with or without ozone treatment as well as retention, marginal discoloration, marginal adaptation and caries formation under in-vivo conditions.

Materials and Methods: The study was carried out on 166 patients whose ages differs between 9-12 and 3 different groups were formed above them according to split-mouth technique. Group 1: Clinpro $^{\mathrm{TM}}$ sealant and Teethmate F-1 were applied on a total of 104 first lower permanent molar teeth. Group 2: Clinpro $^{\mathrm{TM}}$ sealant and Clinpro $^{\mathrm{TM}}$ sealant following ozone treatment were applied on 112 first lower permanent molar teeth. Group 3: Teethmate F-1 and Teethmate F-1 following the ozone treatment were applied on 116 first lower permanent molar teeth. Based on the modified USPHS criteria, the impacts on general achievement, retention, marginal fit, marginal discoloration and caries formation were evaluated in 3rd,6th,12th,18th months. Chi-Square Test and Fisher's Exact Test were used for analyses of the data.

Results: In Group 1; Clinpro ${ }^{\mathrm{TM}}$ sealant showed higher clinical success rates in all observation periods. Considering marginal adaptation and retention, Clinpro $^{\mathrm{TM}}$ sealant group was statistically significantly different in 18th month observations. In group 2 and group 3, there was not statistically significantly difference $(p>0.05)$ between control and experimental groups but clinical success rates of Clinpro ${ }^{\mathrm{TM}}$ sealant and Teethmate F-1 with Ozone Treatment were higher than the same groups without ozone pretreatment for all periods.

Conclusions: It was determined that, Clinpro ${ }^{\mathrm{TM}}$ sealant yielded more successful results than the Teethmate F-1 under in-vivo conditions. Although, statistically significantly difference was not detected in Group 2 and Group 3, the Ozone pretreatment method's success rates were clinically higher as Bravo, Alpha and Charlie Scores. It seems that, Ozone pretreatment is a successful method for preventing pit and fissure sealants, clinically.

Key words: Ozone, fissure sealant, anti-bacterial agents, preventive dentistry.

\author{
(D) Murat Çetinkaya ${ }^{1}$ \\ (D)*Merve Aksoy² \\ (D) Firdevs Tulga Öz $z^{3}$
}

ORCID IDs of the authors:

M.Ç. $\quad 0000-0002-8793-4150$

M.A. $\quad 0000-0003-1577-0289$

F.T.Ö. 0000-0002-8731-5907
Received : : 27.07.2020

Accepted $\quad: 22.09 .2020$

\footnotetext{
How to Cite: Çetinkaya M, Aksoy M, Tulga Öz F. Better with Ozone, Or Not? An In-Vivo Study of Ozone Therapy as A Pre-Treatment Before Fissure Sealant Application. Cumhuriyet Dent J 2020;23:4: 262-272.

*Corresponding Author:

Health Sciences University, Faculty of Gülhane Dentistry, Department of Pedodontics, Ankara, Türkiye.

E-mail: mervekurun@hotmail.com
} 


\section{INTRODUCTION}

Today, preventive dentistry is considered an appropriate approach to halting cariogenic dental infections in both adults and children. Prophylactic methods including fluoride treatment, oral-hygiene education and diet may inhibit smooth-surface caries, but they are less effective against pit-andfissure caries. Fissure sealants are known to be the most effective agents in the prevention of occlusal caries. In general, under clinical conditions, application of a restorative material is the preferred method of treatment for preventing food retention and bacterial adhesion in deep pits and fissures of the teeth. ${ }^{1-3}$ However, the use of resin-based fissure sealants for managing pit-and-fissure caries has also been reported to have a number of drawbacks that can eventually lead to treatment failure, including marginal discoloration, adhesive failure, restoration loss, and caries formation over the long term. In order to improve the success of treatment with resin-based materials, a number of methods have been tried, including pre-treatment with ozone. . $^{4-6}$

Ozone gas is one of the most effective antibacterial agents and antioxidants found in nature, and it has long been used in medicine and dentistry for its healing properties with no reported negative effects on general health. ${ }^{7-9}$ Numerous invitro studies have examined ozone pre-treatment in terms of its antimicrobial activity and its effects on marginal leakage and microleakage of pit-andfissure sealants. ${ }^{10-12} \mathrm{~A}$ number of in-vivo studies have also been conducted to investigate the antimicrobial effects of ozone therapy and the effects of pre-treatment with ozone gas on the success of resin-based materials. ${ }^{13-17}$

Clinpro $^{\mathrm{TM}}$ is a resin-based fluoride-releasing sealant that includes inorganic filler components that is frequently used in clinical practice and that has been featured in many recent studies. ${ }^{18}$ Teethmate F-1 is an unfilled, low-viscosity, resinbased material capable of diffusing through deep pits and fissures. ${ }^{19}$ To date, there has been no invivo study conducted to provide a comparative assessment of the sealants Clinpro ${ }^{\mathrm{TM}}$ and Teethmate F-1 used with and without ozone pretreatment. Therefore, the present study was conducted in order to evaluate and compare the 3-, 6-, 12-, and 18- month clinical success rates of Clinpro $^{\mathrm{TM}}$ and Teethmate $\mathrm{F}-1$ fissure sealants applied with and without ozone pre-treatment in terms of marginal discoloration, marginal adaptation, retention, and caries formation. The hypothesis tested was that ozone pre-treatment enhances the clinical success of fissure sealants.

\section{MATERIAL AND METHODS}

The study protocol was conducted in line with the principles of the Helsinki Declaration, including all amendments and revisions, and with the approval of the Ankara University Faculty of Dentistry's Board of Ethics (Number:137/1). Access to data was restricted to the researchers, and informed consent was obtained from all participants or their legal representatives prior to any treatment.

Sample size was calculated based on previous studies using the Power Analysis and Sample Size (PASS) 2008 Statistical Software (Utah, USA). Accordingly, 166 patients (89 males, 77 female) ranging in age from 9-12 years were included in the study. Following clinical examinations, a total of 332 mandibular permanent first molars were selected and randomly divided into three study groups according to CONSORT guidelines (Figure 1).

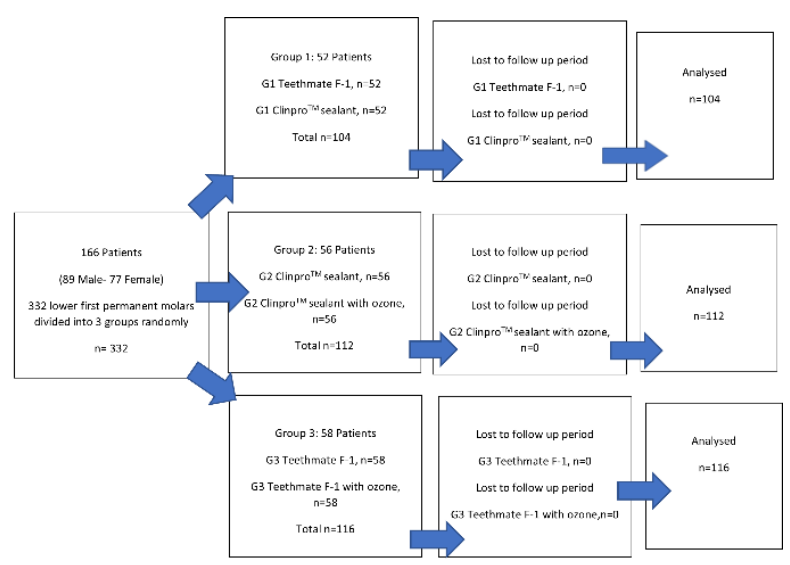

Figure 1. Consort Diagram

Patients were included in the study if their pretreatment medical history showed them to be "completely healthy" according to ASA criteria and if both their left and right mandibular permanent first molars were fully erupted and intact, with no hypo mineralization defects. All other required dental treatment was performed, and patients were given oral-care instruction before initiating the study. 
Prior to sealant application, all tooth surfaces were cleaned with a tooth brush and water ${ }^{20}$, and treated teeth were isolated using a rubber dam in order to avoid bacterial contamination and enhance success rates..$^{21}$ The area surrounding the teeth to be treated were cleaned with alcohol applied on a cotton pellet, and articulation paper was used to eliminate occlusal interferences.

Participants were randomly divided into one of three study groups, and a split-mouth technique was employed in order to evaluate the effects of two different sealant protocols, which were randomly assigned to either the left or right mandibular first molar. Clinpro ${ }^{\mathrm{TM}}$ and Teethmate F-1 sealants with and without ozone pre-treatment were applied as follows:

Group 1: Clinpro ${ }^{\mathrm{TM}}$ sealant vs Teethmate F-1

Clinpro $^{\text {TM: }}$ In line with the manufacturer's recommendation, 37\% phosphoric acid (ETCH-37, Bisco Inc., Schaumburg, USA) was applied for 20 seconds on all pits and fissures. Surfaces were washed with water spray for 15 seconds and dried with air spray, until they were white and opaque. Clinpro $^{\text {TM }}$ sealant (3M ESPE, St. Paul, MN, USA. 20021121) was applied and homogenized using a dental probe and then polymerized using an LED light-curing unit (Elipar Freelight 2, 3M ESPE, Germany) for 20 seconds (Figure 2).

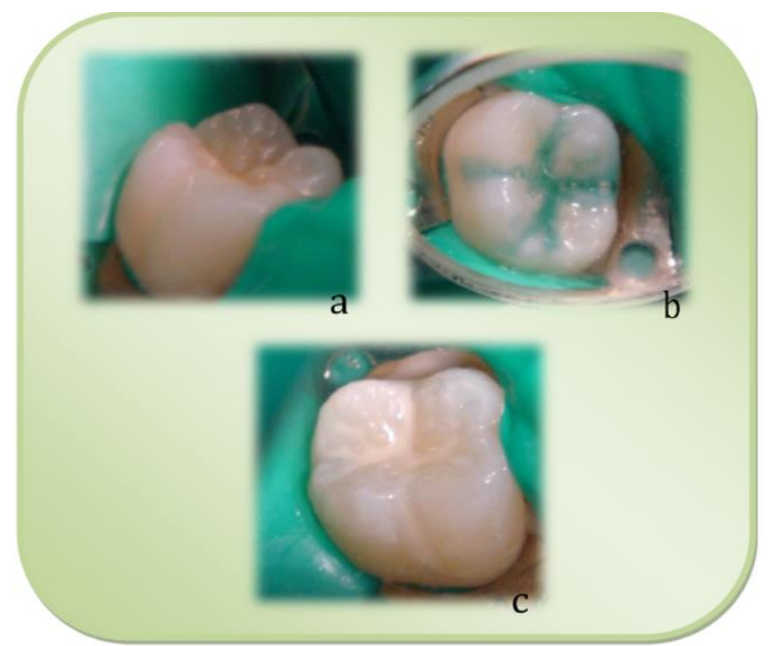

Figure 2. a) G1 Clinpro $^{\mathrm{TM}}$ b) $37 \%$ Phosphoric acid applying, c) Polymerisation of Clinpro ${ }^{\mathrm{TM}}$ sealant.

Teethmate F-1: In line with the manufacturer's recommendation, 40\% phosphoric acid (K-etch, Kuraray Medical, 1621Sakazu, Kurashiki, Okayama 710-8622, Japan) was applied for 20 seconds on all pits and fissures, and surfaces were washed and dried as described above. Teethmate F1 sealant (Kuraray Medical, 1621 Sakazu, Kurashiki, Okayama 710-8622, Japan) was applied and polymerized as described above for Clinpro $^{\mathrm{TM}}$ (Figure 3).

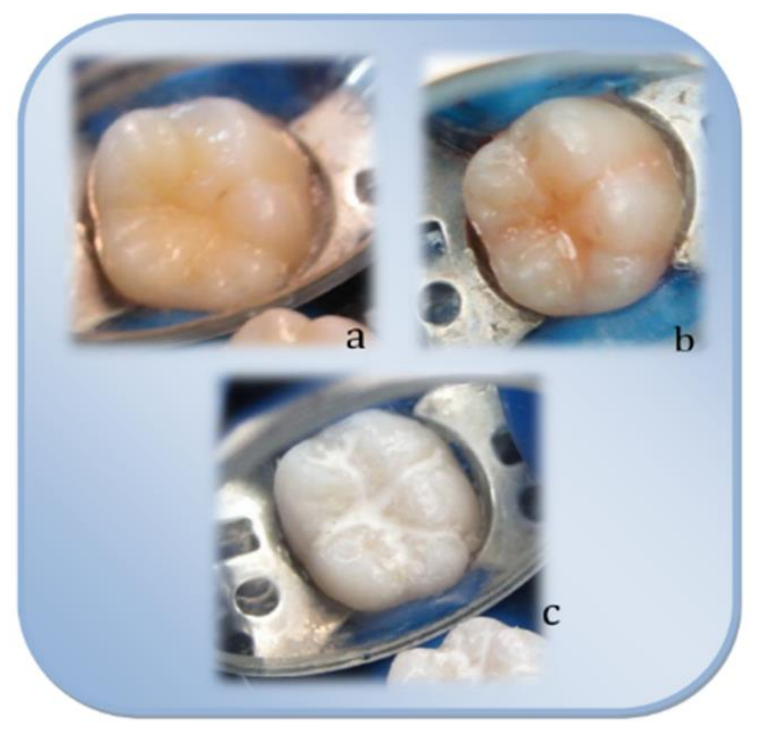

Figure 3. a) G1 Teethmate F-1 First Lower Molar, b) 40\% Phosphoric acid applying, c) Polymerisation of Teethmate F-1.

Group 2: Clinpro $^{\mathrm{TM}}$ vs Clinpro $^{\mathrm{TM}}$ with ozone pretreatment

Clinpro $^{\text {TM: }}$ Acid etching and sealant treatment was performed as described above for Group 1, Clinpro $^{\mathrm{TM}}$.

Clinpro $^{\mathrm{TM}}$ with ozone pretreatment: Ozone pretreatment was performed using Ozonytron $\mathrm{X}$ (Mymed, Germany, 2005), with the CA probe set at $100,000 \mathrm{rpm}$ to apply ozone gas directly on pits and fissures for 30 seconds. Acid etching and sealant treatment was then performed as described above for Group 1, Clinpro ${ }^{\mathrm{TM}}$ (Figure 4).

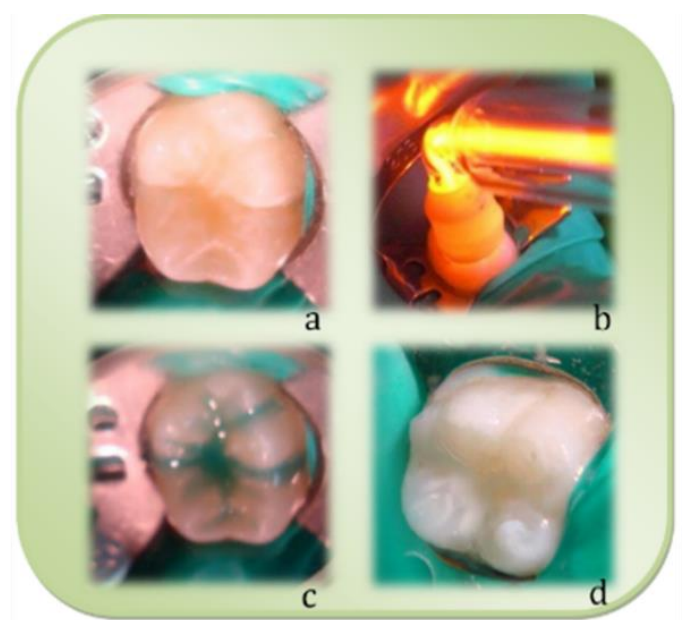

Figure 4. a) G2 Ozone-Clinpro ${ }^{\mathrm{TM}}$ First Lower Molar, b) Ozone applying at occlusal surfaces, c) 37\% Phosphoric acid applying, d) Polymerisation of Clinpro ${ }^{\mathrm{TM}}$ sealant. 
Group 3: Teethmate F-1 vs Teethmate F-1 with ozone pretreatment)

Teethmate F-1: Acid etching and sealant treatment was performed as described above for Group 1, Teethmate F-1.

Teethmate F-1 with ozone pretreatment: Ozone pre-treatment was performed as described above for Group 2, Clinpro ${ }^{\text {TM }}$. Acid etching and sealant treatment was then performed as described above for Group 1, Teethmate F-1 (Figure 5).

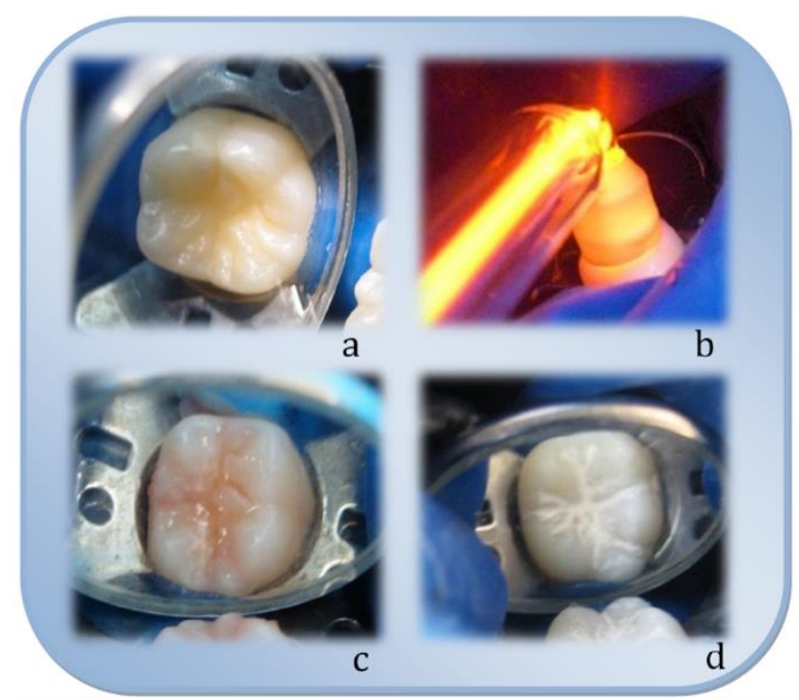

Figure 5. a) G3 Ozone-Teethmate F-1 First Lower Molar, b) Ozone applying at occlusal surfaces, c) $40 \%$ Phosphoric acid applying, d) Polymerisation of Teethmate F-1 sealant.

Clinical examinations were conducted at 3, 6, 12, and 18 months following treatment. Success was based on United States Public Health Service (USPHS) criteria $^{22}$, i.e., retention of fissure sealants, marginal adaptation, marginal discoloration and caries formation. Criteria were evaluated and scored as follows:

Retention. Retention was evaluated by visual inspection. Teeth were scored as either Alpha (Restoration present), Bravo (Partial loss of restoration, but clinically acceptable), or Charlie (Clinically unacceptable partial loss or total loss of restoration.)
Marginal adaptation. Marginal adaptation was evaluated by probing and inspection. Teeth were scored as either Alpha (Continuity at the margin), Bravo (Slight discontinuity at the margin), or Charlie (Marginal ledge or crevice requiring replacement).

Marginal discoloration. Marginal discoloration was evaluated by visual inspection. Teeth were scored as either Alpha (No discoloration at the margin), Bravo (Superficial discoloration at the margin), or Charlie (Deep discoloration at the margin, penetrated in a pulpal direction).

Caries. Caries were evaluated by visual inspection and probing. Teeth were scored as either Alpha (Caries absent) or Charlie (Caries present).

In each examination period, the teeth scored as Charlie for retention were left out assessment for marginal discoloration and caries formation examinations.

\section{Statistical Analysis}

Statistical analysis was performed using the NCSS (Number Cruncher Statistical System) 2007 and PASS (Power Analysis and Sample Size) 2008 Statistical Software (Utah, USA). Analysis included descriptive statistics (frequency-ratio) as well as Chi-Square and Fisher's Exact Tests. The Chi-Square Test relies on an approximation to make a global assessment as to whether the relationship between two variables is independent or associated, but it requires a minimum number of samples, whereas Fisher's exact test can be used with small sample sizes. ${ }^{23}$ Differences of $p<0.05$ were considered statistically significant.

\section{RESULTS}

\section{Clinpro $^{\text {TM }}$ vs Teethmate F-1}

Table 2 presents the overall clinical success and failure at 3, 6, 12, and 18 months for Group 1. 
Table 2. Statistical Analyses of Clinical Success Rates- Group 1

\begin{tabular}{|c|c|c|c|c|c|c|c|c|c|}
\hline \multirow[b]{2}{*}{ Material } & \multirow[b]{2}{*}{ General Success } & \multicolumn{2}{|c|}{ 3rd month } & \multicolumn{2}{|c|}{ 6th month } & \multicolumn{2}{|c|}{ 12th month } & \multicolumn{2}{|c|}{ 18th month } \\
\hline & & $\begin{array}{c}\mathbf{n} \\
(\mathbf{5 2})\end{array}$ & $\begin{array}{c}\% \\
100\end{array}$ & $\underset{(52)}{\mathbf{n}}$ & $\begin{array}{c}\% \\
100\end{array}$ & $\begin{array}{c}\mathbf{n} \\
(\mathbf{5 2})\end{array}$ & $\begin{array}{c}\% \\
100\end{array}$ & $\begin{array}{c}\mathbf{n} \\
(\mathbf{5 2})\end{array}$ & $\begin{array}{c}\% \\
100\end{array}$ \\
\hline \multirow{2}{*}{ Clinpro $^{\mathrm{TM}}$ Sealant } & Successful & 50 & 96.2 & 47 & 90.4 & 44 & 84.6 & 43 & 82.7 \\
\hline & Failure & 2 & 3.8 & 5 & 9.6 & 8 & 15.4 & 9 & 17.3 \\
\hline \multirow{2}{*}{ Teethmate F-1 } & Successful & 49 & 94.2 & 44 & 84.6 & \multicolumn{2}{|c|}{$\begin{array}{c}40 \\
76.9\end{array}$} & 33 & 63.4 \\
\hline & Failure & 3 & 5.8 & 8 & 15.4 & \multicolumn{2}{|c|}{$\begin{array}{c}12 \\
23.1\end{array}$} & 19 & 36.6 \\
\hline p values & \multicolumn{3}{|c|}{0.647} & \multicolumn{2}{|c|}{0.374} & \multicolumn{2}{|c|}{0.320} & \multicolumn{2}{|c|}{$0.016 *$} \\
\hline
\end{tabular}

As the table shows, overall clinical success was significantly higher for Clinpro ${ }^{\mathrm{TM}}$ as compared to Teethmate F-1 at 18 months post-treatment ( $\mathrm{p}<0.05)$. According to Alpha, Bravo, and Charlie scores, no statistically significant differences were observed in any of the individual parameters of retention, marginal adaptation, marginal discoloration, and caries formation at 3, 6, or 12 months. However, at 18 months, statistically significant differences were observed between the two sealants. Retention rates were significantly $(\mathrm{p}<0.05)$ higher for Clinpro ${ }^{\mathrm{TM}}(78.8 \%)$ as compared to Teethmate F-1 (65.4\%). Marginal adaptation scores were also significantly $(\mathrm{p}<0.05)$ higher for Clinpro ${ }^{\mathrm{TM}}(73.1 \%)$ as compared to Teethmate F-1 (53.8\%) (Table 3).

Table 3. Findings obtained through the observation periods for the retention, marginal integrity, marginal discoloration and caries formation based on modified USPHS criteria - Group 1.

\begin{tabular}{|c|c|c|c|c|c|c|c|}
\hline \multirow{2}{*}{$\begin{array}{l}\text { Clinical } \\
\text { Criteria }\end{array}$} & \multirow{2}{*}{$\begin{array}{c}\text { Observation } \\
\text { Periods }\end{array}$} & \multirow{2}{*}{ Score } & \multicolumn{2}{|c|}{ Clinpro $^{\mathrm{TM}}$ Sealant } & \multicolumn{2}{|c|}{$\begin{array}{l}\text { Teethmate } \\
\text { F-1 }\end{array}$} & \multirow{2}{*}{$\mathrm{p}$} \\
\hline & & & $\mathrm{n}$ & $\%$ & $\mathrm{n}$ & $\%$ & \\
\hline \multirow{13}{*}{ Retention } & \multirow{3}{*}{ 3rd month } & Alpha & 49 & 94.2 & 47 & 90.4 & 0.462 \\
\hline & & Bravo & 1 & 1.9 & 2 & 3.8 & 0.558 \\
\hline & & Charlie & 2 & 3.8 & 3 & 5.8 & 0.647 \\
\hline & \multirow{3}{*}{ 6th month } & Alpha & 45 & 86.5 & 45 & 86.5 & 1.00 \\
\hline & & Bravo & 3 & 5.8 & 2 & 3.8 & 0.647 \\
\hline & & Charlie & 4 & 7.7 & 5 & 9.6 & 0.727 \\
\hline & \multirow{3}{*}{12 th month } & Alpha & 42 & 80.8 & 37 & 71.5 & 0.251 \\
\hline & & Bravo & 4 & 7.7 & 7 & 13.5 & 0.339 \\
\hline & & Charlie & 6 & 11.5 & 8 & 15.4 & 0.556 \\
\hline & \multirow{3}{*}{ 18th month } & Alpha & 41 & 78.8 & 34 & 65.4 & $0.036^{*}$ \\
\hline & & Bravo & 5 & 9.6 & 8 & 15.4 & 0.250 \\
\hline & & Charlie & 6 & 11.5 & 10 & 19.2 & 0.277 \\
\hline & \multirow{3}{*}{ 3rd month } & Alpha & 49 & 94.3 & 47 & 90.4 & 0.715 \\
\hline \multirow{11}{*}{$\begin{array}{c}\text { Marginal } \\
\text { Adaptation }\end{array}$} & & Bravo & 1 & 1.9 & 2 & 3.8 & 1.000 \\
\hline & & Charlie & 2 & 5.8 & 3 & 5.8 & 1.000 \\
\hline & \multirow{3}{*}{ 6th month } & Alpha & 44 & 84.6 & 43 & 82.7 & 0.791 \\
\hline & & Bravo & 4 & 7.7 & 3 & 5.8 & 1.000 \\
\hline & & Charlie & 4 & 7.7 & 6 & 11.5 & 0.506 \\
\hline & \multirow{3}{*}{12 th month } & Alpha & 40 & 76.9 & 36 & 69.2 & 0.377 \\
\hline & & Bravo & 5 & 9.6 & 8 & 15.4 & 0.374 \\
\hline & & Charlie & 7 & 13.5 & 8 & 15.4 & 0.780 \\
\hline & \multirow{6}{*}{ 3rd month } & Alpha & 38 & 73.1 & 28 & 53.8 & $0.042 *$ \\
\hline & & Bravo & 6 & 11.5 & 12 & 23.1 & 0.120 \\
\hline & & Charlie & 8 & 15.4 & 12 & 23.1 & 0.320 \\
\hline \multirow{3}{*}{$\begin{array}{c}\text { Marginal } \\
\text { Discolaration }\end{array}$} & & Alpha & 50 & 100 & 49 & 100 & 1.000 \\
\hline & & Bravo & - & - & - & - & - \\
\hline & & Charlie & - & - & - & - & - \\
\hline
\end{tabular}




\begin{tabular}{|c|c|c|c|c|c|c|c|}
\hline & \multirow{3}{*}{ 6th month } & Alpha & 47 & 97.9 & 45 & 97.8 & 1.000 \\
\hline & & Bravo & 1 & 2.1 & 1 & 2.2 & 1.000 \\
\hline & & Charlie & - & - & - & - & - \\
\hline & \multirow{3}{*}{ 12th month } & Alpha & 43 & 93.5 & 40 & 90.9 & 0.429 \\
\hline & & Bravo & 2 & 4.3 & 4 & 9.1 & 0.429 \\
\hline & & Charlie & - & - & - & - & - \\
\hline & \multirow{3}{*}{ 18th month } & Alpha & 38 & 86.4 & 34 & 82.9 & 0.660 \\
\hline & & Bravo & 5 & 11.4 & 5 & 14.6 & 1.000 \\
\hline \multirow{9}{*}{$\begin{array}{l}\text { Caries } \\
\text { Formation }\end{array}$} & & Charlie & 1 & 2.3 & 1 & 2.4 & 1.000 \\
\hline & \multirow{2}{*}{ 3rd month } & Alpha & 52 & 100 & 52 & 100 & 1.000 \\
\hline & & Charlie & - & - & - & - & - \\
\hline & \multirow{2}{*}{ 6th month } & Alpha & 50 & 100 & 49 & 100 & 1.000 \\
\hline & & Charlie & - & - & - & - & - \\
\hline & \multirow{2}{*}{12 th month } & Alpha & 48 & 100 & 46 & 100 & 1.000 \\
\hline & & Charlie & - & - & - & - & - \\
\hline & \multirow{2}{*}{ 18th month } & Alpha & 44 & 97.8 & 42 & 95.5 & 1.000 \\
\hline & & Charlie & 1 & 2.2 & 2 & 4.5 & 1.000 \\
\hline
\end{tabular}

$* \mathrm{p}<0.05$

Marginal discoloration did not vary significantly between Clinpro $^{\mathrm{TM}}$ and Teethmate $\mathrm{F}-1$ at 18 months $(\mathrm{p}<0.05)$ and although caries formation was detected in 1 tooth treated with Clinpro ${ }^{\mathrm{TM}}$ and 2 teeth treated with Teethmate F-1, the difference was not statistically significant.

\section{Clinpro $^{\mathrm{TM}}$ vs Clinpro ${ }^{\mathrm{TM}}$ with Ozone Therapy}

Clinpro $^{\mathrm{TM}}$ with Ozone Therapy showed higher overall clinical success rates than Clinpro $^{\mathrm{TM}}$ without Ozone Therapy at 3, 6,12 and 18 months, but the differences were not statistically significantly $(\mathrm{p}>0.05)$. No statistically significantly differences $(p>0.05)$ were observed in any of the individual criteria during any of the observation periods (Table 4).

Table 4. Findings obtained through the observation periods for the retention, marginal integrity, marginal discoloration, and caries formation based on modified USPHS criteria - Group 2.

\begin{tabular}{|c|c|c|c|c|c|c|c|}
\hline \multirow{2}{*}{ Clinical } & \multirow{2}{*}{ Observation } & \multirow{2}{*}{ Score } & \multicolumn{2}{|c|}{ Clinpro $^{\mathrm{TM}}$ Sealant } & \multicolumn{2}{|c|}{ Ozone- Clinpro ${ }^{\mathrm{TM}}$ Sealant } & \multirow{2}{*}{$\mathrm{p}$} \\
\hline & & & $\mathrm{n}$ & $\%$ & $\mathrm{n}$ & $\%$ & \\
\hline \multirow{12}{*}{ Retention } & \multirow{3}{*}{ 3rd month } & Alpha & 53 & 94.6 & 55 & 98.2 & 0.618 \\
\hline & & Bravo & - & & - & & - \\
\hline & & Charlie & 3 & 5.4 & 1 & 1.8 & 0.618 \\
\hline & \multirow{3}{*}{ 6th month } & Alpha & 47 & 83.9 & 49 & 87.5 & 0.589 \\
\hline & & Bravo & 4 & 7.1 & 4 & 7.1 & 1.000 \\
\hline & & Charlie & 5 & 8.9 & 3 & 5.4 & 0.716 \\
\hline & \multirow{3}{*}{ 12th month } & Alpha & 44 & 78.6 & 47 & 83.9 & 0.468 \\
\hline & & Bravo & 5 & 8.9 & 4 & 7.1 & 1.000 \\
\hline & & Charlie & 7 & 12.5 & 5 & 8.9 & 0.541 \\
\hline & \multirow{3}{*}{ 18th month } & Alpha & 43 & 76.8 & 45 & 80.4 & 0.645 \\
\hline & & Bravo & 5 & 8.9 & 5 & 8.9 & 1.000 \\
\hline & & Charlie & 8 & 14.3 & 6 & 10.7 & 0.568 \\
\hline \multirow{9}{*}{$\begin{array}{c}\text { Marginal } \\
\text { Adaptation }\end{array}$} & \multirow{3}{*}{ 3rd month } & Alpha & 53 & 94.6 & 55 & 98.2 & 0.618 \\
\hline & & Bravo & 0 & 0 & 0 & 0 & - \\
\hline & & Charlie & 3 & 5.4 & 1 & 1.8 & 0.618 \\
\hline & \multirow{3}{*}{ 6th month } & Alpha & 46 & 82.2 & 47 & 83.9 & 0.801 \\
\hline & & Bravo & 5 & 8.9 & 5 & 8.9 & 1.000 \\
\hline & & Charlie & 5 & 8.9 & 4 & 7.2 & 1.000 \\
\hline & \multirow{3}{*}{12 th month } & Alpha & 42 & 75.0 & 44 & 78.6 & 0.654 \\
\hline & & Bravo & 6 & 10.7 & 5 & 8.9 & 0.751 \\
\hline & & Charlie & 8 & 14.3 & 7 & 12.5 & 0.781 \\
\hline
\end{tabular}


Çetinkaya M., et al.

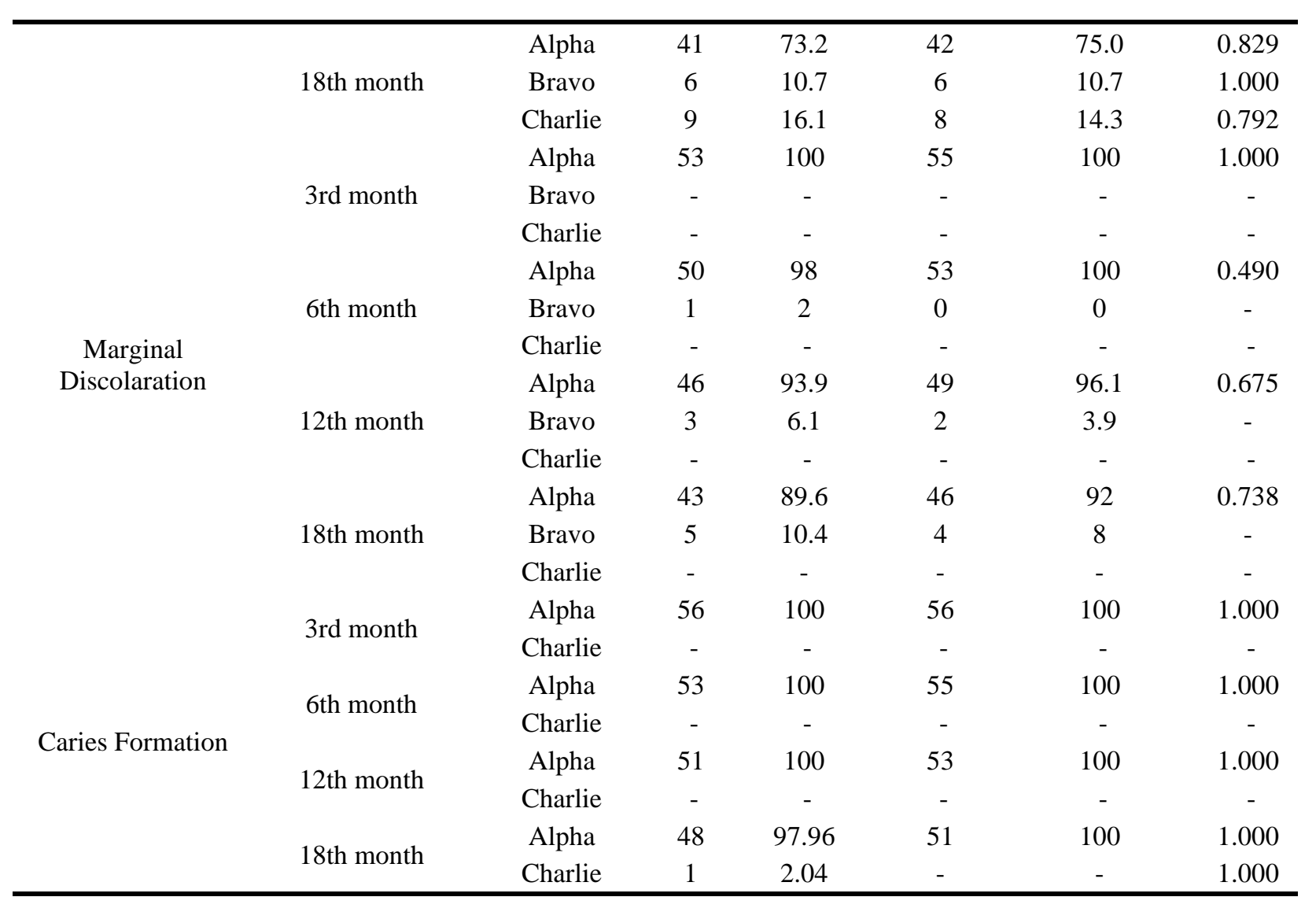

With the exception of 1 caries that was observed at 18 months in a tooth treated using Clinpro $^{\mathrm{TM}}$ Sealant without Ozone Therapy, no caries was detected in Group 2.

\section{Teethmate F-1 vs Teethmate F-1 with Ozone Therapy}

Teethmate F-1 with ozone therapy showed a higher overall clinical success rate than Teethmate F-1 without Ozone Therapy at 3, 6, 12 and 18 months, but the differences were not statistically significantly $(p>0.05)$. No statistically significant differences were observed in retention, marginal adaptation, or marginal discoloration during any of the observation periods (Table 5). With the exception of 2 caries observed at 18 months in a tooth treated using Teethmate F-1 without Ozone Therapy, no caries was detected in Group 3.

Table 5. Findings obtained through the observation periods for the retention, marginal integrity, marginal discoloration, and caries formation based on modified USPHS criteria - Group 3

\begin{tabular}{|c|c|c|c|c|c|c|c|}
\hline \multirow{2}{*}{ Clinical } & \multirow{2}{*}{ Observation } & \multirow{2}{*}{ Score } & \multicolumn{2}{|c|}{ Teethmate F-1 } & \multicolumn{2}{|c|}{ Ozone- Teethmate F-1 } & \multirow{2}{*}{$\mathrm{p}$} \\
\hline & & & $\mathrm{n}$ & $\%$ & $\mathrm{n}$ & $\%$ & \\
\hline \multirow{12}{*}{ Retention } & \multirow{3}{*}{ 3rd month } & Alpha & 53 & 91.4 & 54 & 93.1 & 1.000 \\
\hline & & Bravo & 2 & 3.4 & 2 & 3.4 & 1.000 \\
\hline & & Charlie & 3 & 5.2 & 2 & 3.4 & 1.000 \\
\hline & \multirow{3}{*}{ 6th month } & Alpha & 51 & 87.9 & 51 & 87.9 & 1.000 \\
\hline & & Bravo & 3 & 5.2 & 3 & 5.2 & 1.000 \\
\hline & & Charlie & 4 & 9.6 & 4 & 6.9 & 1.000 \\
\hline & \multirow{3}{*}{ 12th month } & Alpha & 42 & 72.4 & 44 & 75.9 & 0.672 \\
\hline & & Bravo & 8 & 13.8 & 7 & 12.1 & 0.782 \\
\hline & & Charlie & 8 & 13.8 & 7 & 12.1 & 0.782 \\
\hline & \multirow{3}{*}{ 18th month } & Alpha & 38 & 65.5 & 39 & 67.2 & 0.844 \\
\hline & & Bravo & 9 & 15.5 & 9 & 15.5 & 1.000 \\
\hline & & Charlie & 11 & 19 & 10 & 17.2 & 0.809 \\
\hline \multirow{2}{*}{ Marginal Adaptation } & \multirow{2}{*}{ 3rd month } & Alpha & 53 & 91.4 & 54 & 93.2 & 1.000 \\
\hline & & Bravo & 2 & 3.4 & 2 & 3.4 & 1.000 \\
\hline
\end{tabular}




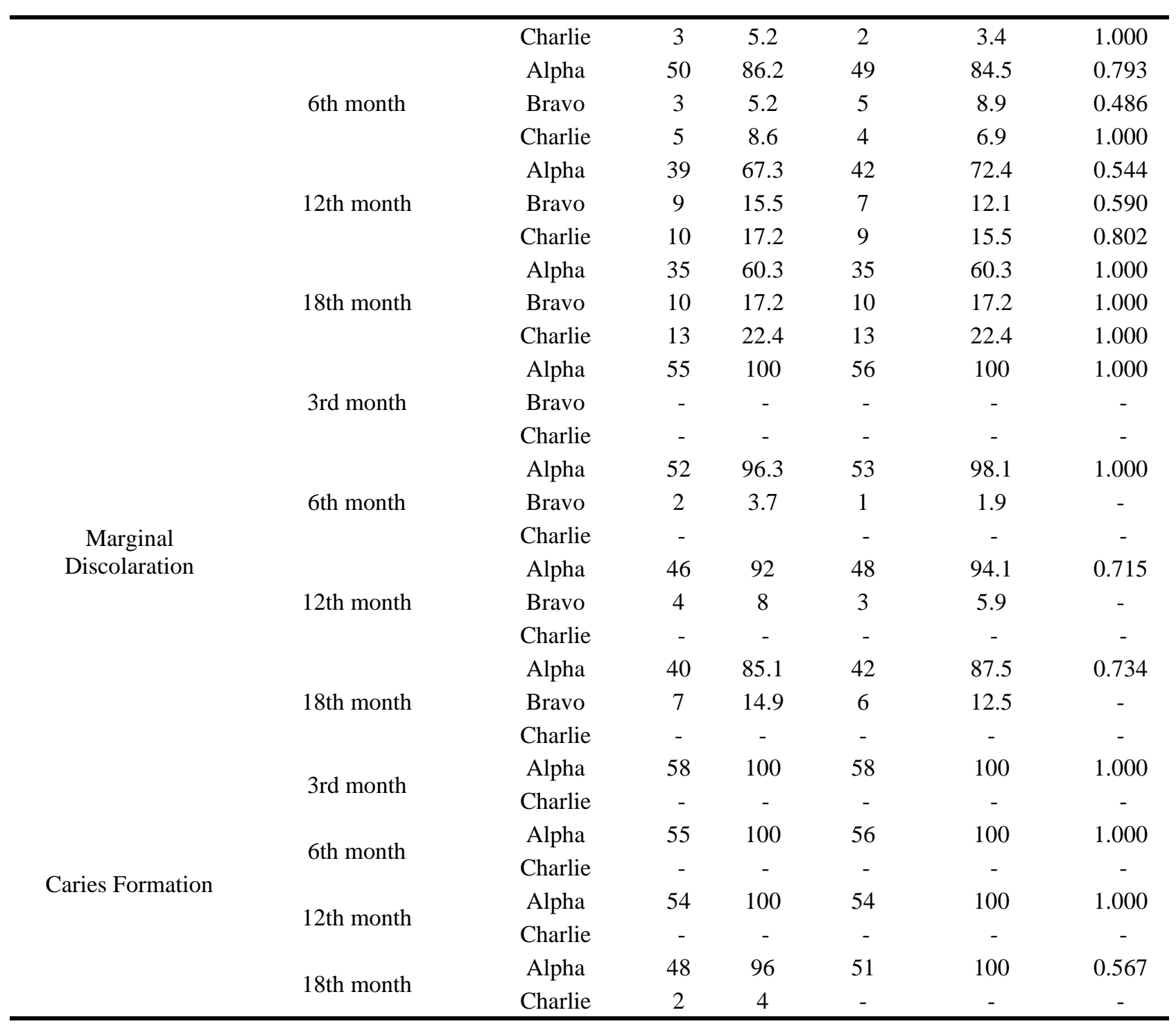

\section{DISCUSSION}

Fissure sealants are considered an important form of treatment for the prevention of occlusal caries. ${ }^{1,3}$ In order to enhance the clinical success of sealant application, a variety of different techniques and materials have been investigated, including ozone therapy. ${ }^{18}$

Ozone has long been known for its antibacterial activity and is used in dentistry as a prophylactic to halt the progression of early-stage caries. Ozone's oxidation capacity reduces bacterial plaque formation. The healing activity associated with ozone is attributed to its ability to maintain an antibacterial environment. Once this environment is secured, recover is achieved through the self-healing capacity of the affected tissue. $^{8}$

In-vivo studies offer the most reliable method for assessing clinical success rates of treatment techniques and materials used in the mouth because intraoral conditions like occlusal forces and temperature and humidity changes cannot be accurately reproduced in-vitro. ${ }^{24}$ Moreover, due to the uniqueness of the oral environment, which varies among individuals ${ }^{25}$, this study was conducted as an in-vivo study with a split-mouth design that compared treatment of left and right mandibular permanent first molars in the same subject.

The mandibular first molars are the first permanent teeth to erupt in the oral environment, placing them at higher risk than other teeth in terms of bacterial accommodation and caries. Clinically, fissure sealants are most often used to treat the occlusal surfaces of first mandibular molars. According to an earlier clinical study, mandibular first molars have higher treatment success rates than maxillary first molars. ${ }^{26}$ For this reason, the 
present study was conducted with mandibular permanent first molars.

In line with other previous studies, the present study used a rubber dam to isolate teeth and avoid bacterial contamination. ${ }^{21}$ Prior to treatment, occlusal surfaces were cleaned with water and burs only; pumice was not used, since Scanning Electron Microscopy (SEM) studies have shown small particles to remain trapped in pits and fissures. ${ }^{20}$ Etching with phosphoric acid was performed according to the manufacturers' instructions (20 seconds with 35\% phosphoric acid for Clinpro ${ }^{\mathrm{TM}}$ and 20 seconds with $40 \%$ phosphoric acid etching for Teethmate F-1). Light-curing was performed with an LED light source because LED lights have been shown to provide better polymerization activity than halogen lights. ${ }^{27}$

Ozone therapy may be performed either before or after the application of a fissure sealant. Previous studies have examined the effects of ozone therapy as a prophylactic before application of a sealant; therefore, this method was also used in the present study. ${ }^{10}$

Previous studies have shown pre-treatment with ozone to have a favourable effect on the penetration and bond strength of resin-based materials to enamel. ${ }^{4,14,27}$ Ozone has also been shown to reduce marginal leakage of fissure sealants in vitro. ${ }^{5,12}$ For example, in an in-vitro study by Cehreli et al. ${ }^{5}$, fissure sealant (Fissurit FX) was applied to extracted molars either with or without ozone pre-treatment and with or without application of a bonding agent (Clearfil Protect Bond); SEM evaluation conducted following thermocycling and basic fuchsine dyeing found ozone treatment to significantly improve marginal adaptation and decrease marginal leakage $(\mathrm{p}<0.001)$.

In a previous in-vivo study by Baysan and Lynch $^{28}$ comparing the remineralization of root surfaces when sealant was used with and without ozone treatment, ECM (Electronic Caries Monitor) and DIAGNOdent values showed a significantly higher level of remineralization occurred with ozone treatment $(\mathrm{p}<0.05)$. Another previous invivo study examined both remineralization and retention of teeth treated with three different fissure sealants (Fuji Triage, Aegis FS, Helioseal) with and without ozone pre-treatment. Retention rates were measured at 1, 3, 6, 9, 12 months, and at the end of 12 months, sealant restorations were removed using an air-abrasion device, and DIAGNOdent scores were measured to compare remineralization values before and after treatment. According to the study report, ozone application improved remineralization for all groups; however, based on DIAGNOdent scores, the increases in remineralization observed with Fuji Triage and Aegis FS following ozone treatment were significantly higher $(\mathrm{p}<0.05)$ than those observed with Helioseal following ozone treatment. ${ }^{15}$ These findings were similar with the recent study, though statistically significant results were not detected in.

\section{CONCLUSIONS}

The clinical performance of Clinpro ${ }^{\mathrm{TM}}$ sealant was found to be significantly better than Teethmate F-1 in terms of retention and marginal adaptation $(p<0.05)$. While ozone pre-treatment improved the success rates of both these fissure sealants, the differences were not statistically significantly ( $>0.05)$. However, given the antimicrobial effects of ozone treatment and the importance of securing an antibacterial environment before performing any restorations, ozone therapy may be recommended before the application of a fissure sealant.

\section{CONFLICTS OF INTEREST STATEMENT}

The authors declare no conflicts of interest.

\section{Ozon Tedavisi Uygulanan ve Uygulanmayan İki Fissür Örtücünün In-Vivo Koşullarda Değerlendirilmesi}

$\ddot{O} Z$

Amaç: Bu çalı̧̧anin amacl, ozon tedavisi uygulanan ve uygulanmayan Clinpro $^{T M}$ sealant ve Teethmate F-1 fissür örtücülerin genel klinik başarılarının yanı sıra tutuculuk, kenar renklenmesi, kenar bütünlüğ̈̈ ve çürük oluşumlarının in-vivo koşullarda değerlendirilmesidir. Gereç ve Yöntemler: Yaşları 9-12 arasında değişen 166 hasta çalışmaya dahil edilmiştir ve 3 farkl grup oluşturulmuştur. Grup-1'de 104 adet rastgele seçilen alt daimî birinci büyük azı dişine Clinpro ${ }^{T M}$ sealant ve Teethmate F-1 uygulanirken; Grup-2'de 112 adet rastgele seçilen alt daimî birinci büyük azı dişine Clinpro $^{T M}$ sealant ve ozon tedavisinden sonra Clinpro ${ }^{T M}$ sealant; Grup-3'te 116 adet rastgele seçilen alt daimî 
birinci büyük azl dişine Teethmate F-1 ve ozon tedavisi sonrasında Teethmate F-1 uygulanmıştır. Tedaviden sonra 3., 6., 12. ve 18. aylarda, genel başarl, tutuculuk, kenar bütünlüğ̈̈, kenar renklenmesi ile oklüzal yüzeylerdeki çürük oluşumları USPHS kriterlerine göre değerlendirilmiştir. Bulgular: Grupl'de, Clinpro ${ }^{T M}$ sealant'in Teethmate F-1'e göre tüm gözlem periyotlarında genel başarısının daha yüksek olduğu ve aradaki farkın 18. ayda istatistiksel olarak anlam kazandiğ $(p<0,05)$, Grup-2 ve Grup-3'te istatistiksel olarak anlamlı bir fark olmamakla birlikte ozon tedavisi uygulanan gruplarda genel başarının daha yüksek olduğu tespit edilmiştir ( $p>0,05)$. Örtücülerin tutuculuk ve kenar bütünlüğ̈̈ değerlendirildiğinde Grup-1'de, Clinpro $^{T M}$ sealant'ın Teethmate F-1'e göre 18.ayda daha başarılı olduğu $(p<0,05)$, kenar renklenmesi

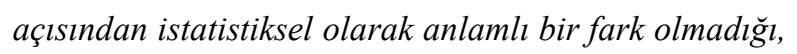
Grup-2 ve Grup-3'te ozon tedavisi uygulanan ve uygulanmayan fissür örtücüler arasında tutuculuk, kenar renklenmesi, kenar bütünlüğü açısından istatistiksel olarak anlamlı bir fark bulunmadı̆̆g tespit edilmiştir $(p>0,05)$. Sonuç: Clinpro $^{T M}$ sealant, Teethmate F-1'e göre istatistiksel olarak daha başarll bulunmuş fakat fissür örtücü öncesi yapılan ozon tedavisinin genel başarl ve tutuculuk, kenar bütünlüğü, kenar renklenmesi, çürük gelişimi üzerindeki etkilerinin istatistiksel olarak anlamlı bir fark yaratmadiğg tespit edilmiştir. Anahtar Kelimeler: Ozon, fissür örtücüler, çocuk diş hekimliği.

\section{REFERENCES}

1. Paglia L, Ferrazzano G, Beretta M. The role of pit and fissure sealants in the prevention of dental caries. In: Bekes K. (eds) Pit and Fissure Sealants. Cham: Springer 2018:35-50.

2. Azarpazhooh A, Main PA. Pit and fissure sealants in the prevention of dental caries in children and adolescents: A systematic review. J Can Dent Assoc 2008;74:171-177.

3. Hou J, Gu Y, Zhu L, Hu Y, Sun M, Xue H. Systemic review of the prevention of pit and fissure caries of permanent molars by resin sealants in China. J Investig Clin Dent Pediatr Dent 2017;8:1-7.

4. Dukić W, Dukić OL, Milardović S. The influence of Healozone on microleakage and fissure penetration of different sealing materials. Coll Antropol 2009;33:157162.

5. Cehreli SB, Yalcinkaya Z, Guven-Polat G, Çehreli ZC. Effect of ozone pretreatment on the microleakage of pit and fissure sealants. J Clin Pediatr Dent 2010;35:187-190.

6. Kapdan A, Öztaş N, Sümer Z. Comparing the antibacterial activity of gaseous ozone and chlorhexidine solution on a tooth cavity model. J Clin Exp Dent 2013;5:133-137.

7. Baysan A, Lynch E. The use of ozone in dentistry and medicine. Prim Dent Care 2005;12:47-52.

8. Azarpazhooh A, Limeback $H$. The application of ozone in dentistry: A systematic review of literature. J Dent 2008;36:104-116.

9. Almaz ME, Sönmez IŞ. Ozone therapy in the management and prevention of caries. J Formos Med Assoc 2015;114:3-11.

10. Cehreli SB, Guzey A, Arhun N, Cetinsahin A, Unver B. The effects of prophylactic ozone pretreatment of enamel on shear bond strength of orthodontic brackets bonded with total or self-etch adhesive systems. Eur J Dent 2010;4:367-373.

11. Öznurhan F, Buldur B, Ozturk C, Durer A. Effects of different cavity disinfectant procedures on microtensile bond strength of permanent teeth. Cumhur Dent J 2015;18:170-179.

12. Kapdan A, Öztaş N. Effects of chlorhexidine and gaseous ozone on microleakage and on the bond strength of dentin bonding agents with compomer restoration on primary teeth. J Dent Sci 2015;10:46-54.

13. Unal M, Oztas N. Remineralization capacity of three fissure sealants with and without gaseous ozone on noncavitated incipient pit and fissure caries. J Clin Pediatr Dent 2015;39:364-370.

14. Yeşilöz Gökçen E, Aksoy M, Orhan AI, Özçelik B, Tulga Öz F. Assessment of the effectiveness of ozone theraphy and an antibacterial bonding agent on the cavity disinfection of deciduous teeth: An in vivo study. Cumhur Dent J 2019;22:442-450.

15. Ghobashy S, El-Tokhey H. In vivo study of the effectiveness of ozonized olive oil gel on inhibiting enamel demineralization during orthodontic treatment. Egypt Orthod J 2012;41:93-113.

16. Kalnina J, Care R. Prevention of occlusal caries using a ozone, sealant and fluoride varnish in children. Stomatologija 2016;18:26-31.

17. Atabek D, Oztas N. Effectiveness of ozone with or without the additional use of remineralizing solution on non-cavitated fissure carious lesions in permanent molars. Eur J Dent 2011;5:393-399.

18. An J, Park H, Seo H, Lee S. Antibacterial properties 
of pit and fissure sealant containing S-PRG filler on Streptococcus mutans. J Korean Acad Pediatr Dent 2015;42:302-311.

19. Dukic W, Glavina D. Clinical evaluation of three fissure sealants: 24 month follow-up. Eur Arch Paediatr Dent 2007;8:163-166.

20. Symons AL, Chu C-Y, Meyers IA. The effect of fissure morphology and pretreatment of the enamel surface on penetration and adhesion of fissure sealants. J Oral Rehabil 1996;23:791-798.

21. Wang Y, Li C, Yuan H, et al. Rubber dam isolation for restorative treatment in dental patients. Cochrane Database Syst Rev 2016;20:CD009858.

22. Cerutti A, Barabanti N, Özcan M. Clinical performance of posterior microhybrid resin composite restorations applied using regular and high-power mode polymerization protocols according to USPHS and SQUACE criteria:10-year randomized controlled splitmouth trial. J Adhes Dent 2020;22:343-351.

23. Kim H-Y. Statistical notes for clinical researchers: Chi-squared test and Fisher's exact test. Restor Dent Endod 2017;42:152-155.

24. Yazici AR, Kiremitçi A, Çelik Ç, Özgünaltay G,
Dayangaç B. A two-year clinical evaluation of pit and fissure sealants placed with and without air abrasion pretreatment in teenagers. J Am Dent Assoc 2006;137(10):1401-1405.

25. Yengopal V, Mickenautsch S, Bezerra AC, Leal SC. Caries-preventive effect of glass ionomer and resinbased fissure sealants on permanent teeth: a meta analysis. J Oral Sci 2009;51:373-382.

26. Vallejos-Sánchez AA, Medina-Solís CE, CasanovaRosado JF, Maupomé G, Minaya-Sánchez M, PérezOlivares S. Caries increment in the permanent dentition of Mexican children in relation to prior caries experience on permanent and primary dentitions. J Dent. 2006;34:709-715.

27. Celiberti P, Pazera P, Lussi A. The impact of ozone treatment on enamel physical properties. Am J Dent 2006;19:67-72.

28. Baysan A, Lynch E. Clinical reversal of root caries using ozone: 6-month results. Am J Dent 2007;20:203208. 